\title{
THE WORK OF THE LEFT VENTRICLE IN AORTIC INSUFFICIENCY
}

\author{
BY EMMET B. BAY
}

(From the Department of Medicine of the University of Chicago and the Douglas Smith

Foundation for Medical Research, Chicago)

(Received for publication June 22, 1936)

Until recently there has been no unanimity of opinion among physiologists and clinicians about the amount of blood which regurgitates into the left ventricle during diastole in the presence of aortic insufficiency. Estimates have ranged from an impression that it must be a considerable amount $(1,2)$ to an idea which assumed a mini- mal backward movement of blood as compared to pressure $(3,4)$. Wiggers, at one time chief proponent of the latter theory, has agreed since 1930 that up to 60 per cent of the tidal volume may regurgitate (5).

On a suitable schema of the circulation (6) (Figure 1) with a fixed actual stroke it can read-

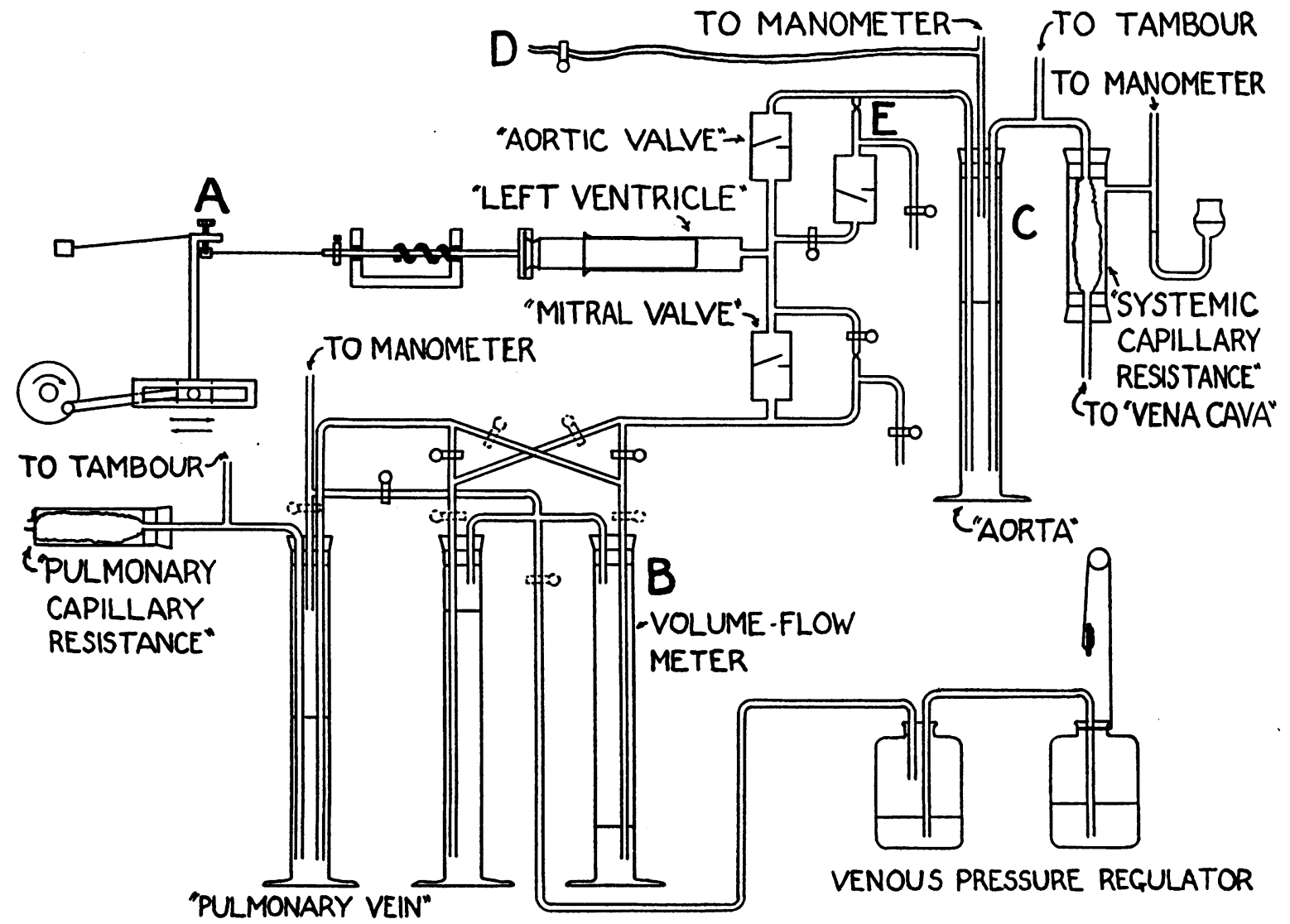

Fig. 1. Diagram of One-Half of the Schema.

Important features are: (1) Stroke volume can be minutely varied at $A$ and volume flow accurately measured at $B$ by Stromuhr technic. (2) Elasticity in "arteries" may be increased in two ways : introducing air in chamber, $C$, or having longer lengths of rubber tube, $D$, in the system. (3) A fixed or variable leak may be introduced in the "aortic valve" at point $E$. (4) Rate can be and was made slow enough to prevent artefacts in the readings of the mercury manometers employed. (5) Capillary resistance may be altered by varying the height of the mercury bulb to the right which controls the water pressure on the outside of the sponge-filled, thin-walled rubber tube used as the "capillary bed." 
ily be demonstrated that there is progressive diminution in output per beat with increase in the amount of "aortic" insufficiency up to a point
(Table I). There is an accompanying drop in mean "arterial" pressure and an increase in "pulse" pressure. Further increase in the size

TABLE I

Effect of increasing the amount of aortic insufficiency on stroke volume in the schema

\begin{tabular}{c|c|c|c|c}
\hline \hline $\begin{array}{c}\text { Experiment } \\
\text { number }\end{array}$ & $\begin{array}{c}\text { Output per } \\
\text { beat }\end{array}$ & $\begin{array}{c}\text { Pulse } \\
\text { pressure }\end{array}$ & Leak & Remarks \\
\hline & $c c$. & $m m . H g$ & $c c$. & \\
1 & 1.25 & 41 & 0 & Intact valves \\
2 & 1.15 & 45 & 0.1 & Aortic leak, actual stroke unchanged \\
3 & 1.06 & 50 & 0.19 & Larger leak, actual stroke unchanged \\
4 & 0.97 & 53 & 0.28 & Larger leak, actual stroke unchanged \\
5 & 0.83 & 58 & 0.42 & Larger leak, actual stroke unchanged \\
6 & 0.55 & 62 & 0.70 & Larger leak, actual stroke unchanged \\
7 & 0.42 & 63 & 0.83 & Larger leak, actual stroke unchanged \\
8 & 1.20 & 125 & 2.16 & Leak as in 7, stroke increased (compensation?) \\
9 & 3.41 & & 0 & Intact valves, stroke as in 8 \\
\hline
\end{tabular}

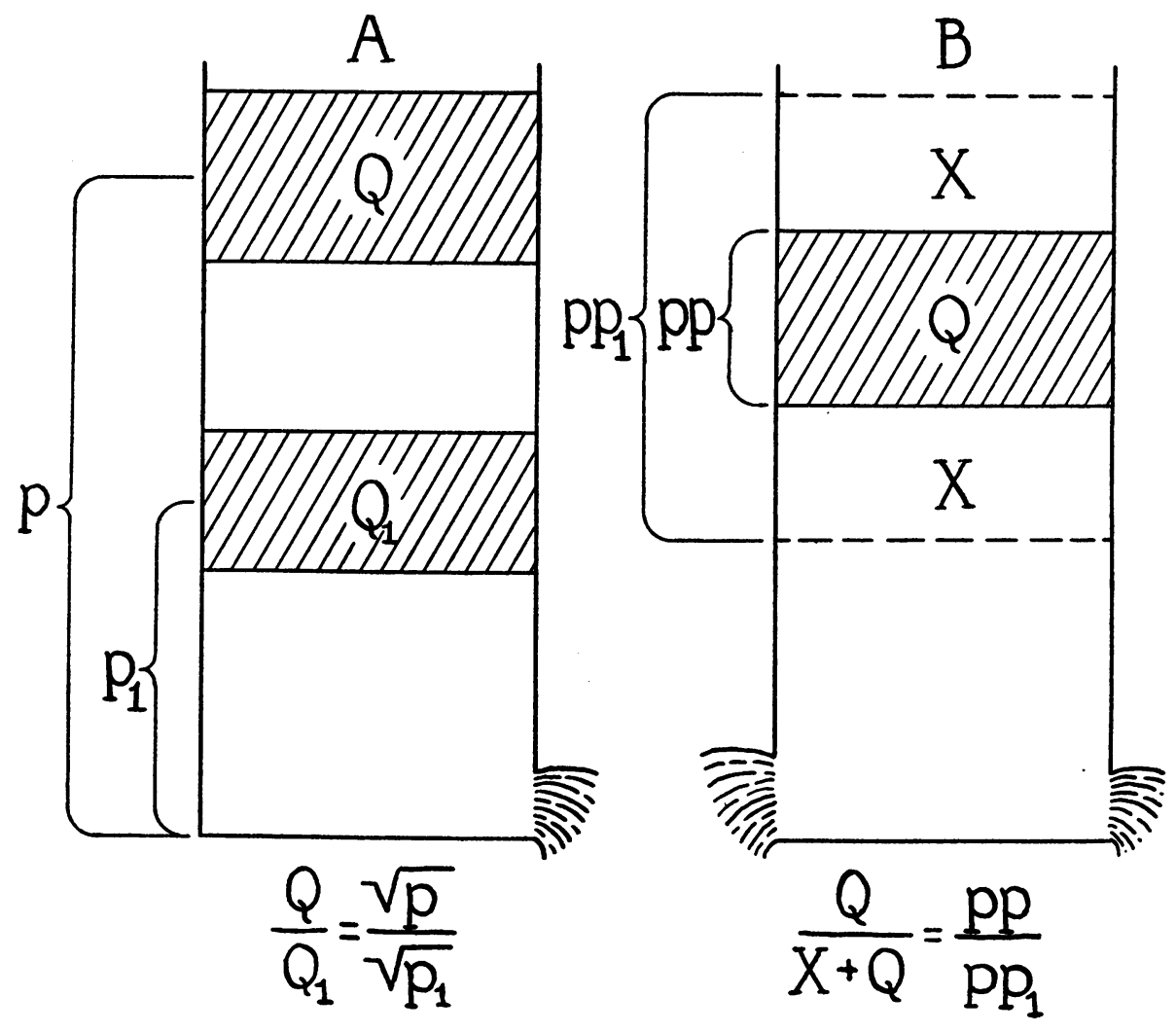

FIG. 2.

$A$ represents a standpipe with an opening at the bottom. The amount flowing out of the opening in unit time is proportional to the square root of the mean head of pressure. $B$ represents a standpipe with an additional opening at the bottom. The amount flowing from both openings is proportional to the amount flowing from the original opening alone as are their respective differences in height (pulse pressures). The amount flowing from one opening alone is equal to the amount flowing from that opening in the presence of an additional opening only if the mean pressures in the two conditions are equal. 
of the leak has no effect upon the output or the pressure relationships unless "compensation" is attempted by increasing the actual stroke. Increasing the latter sufficiently results in a larger amount of regurgitation and a restoration of mean pressure and output per beat and a further increase in pulse pressure. A factor which may modify these results on the schema is the presence of a dominant "right ventricle" acting strongly enough to determine the volume output of the system at all times-a situation not encountered in animal or human physiology. Excluding right ventricular activity, by using onehalf of the model only, a typical experiment in which peripheral resistance and elasticity in the system were kept constant has already been mentioned (Table I).

An approximate estimate of the amount of fluid which regurgitates after "compensation" has been established may be made by using only factors which are measurable in intact animals, assumptions which seem valid to me, and by employing physical formulae which are known. The calculation will be better understood by reference to Figure 2 which represents a stand-pipe with an outlet at the bottom. An old conception in hydraulics first proposed by Torricelli in 1660 (7) states that the quantity flowing out in unit time is theoretically expressed in the following equation :

$$
Q=a \sqrt{2 g h},
$$

where $Q$ is quantity, $a$ is area of opening, $g$ is the force of gravity and $h$ is mean height or mean head of pressure. Friction, viscosity and other factors are known to influence this theoretical calculation, so that in practice a constant is necessary to make it accurate and usable in estimating any one of the factors separately. But relations between two of the factors do not require the use of the constant for accuracy.

$$
\frac{Q}{Q_{l}}=\frac{\sqrt{h}}{\sqrt{h_{l}}}
$$

is well established if other factors remain unchanged.

If the assumption is made that there is no change in the size of the capillaries in the basal state this conception makes possible the calculation, when the heart is normal, of systolic and diastolic volume flow from the arteries to the capillaries by the equation:

$$
\begin{aligned}
\frac{Q_{d}}{V-Q_{d}} & =\frac{T_{d} \sqrt{p_{d}-p_{c}}}{T_{s} \sqrt{p_{s}-p_{c}}}, \\
Q_{d} & =\frac{V T_{d} \sqrt{p_{d}-p_{c}}}{T_{s} \sqrt{p_{s}-p_{c}}+T_{d} \sqrt{p_{d}-p_{c}}},
\end{aligned}
$$

where $Q_{d}$ is diastolic flow, $V$ is total flow per beat, $T_{d}$ and $T_{s}$ are diastolic and systolic time, and $p_{d}, p_{s}$ and $p_{c}$ are diastolic, systolic and capillary mean pressures, respectively.

With the same assumption it also permits the calculation of diastolic flow to the capillaries in the presence of an aortic leak and reduced mean diastolic arterial pressure:

$$
\begin{aligned}
& \frac{Q_{d}}{Q_{l}}=\frac{\sqrt{p_{d}-p_{c}}}{\sqrt{p_{d l}-p_{c}}}, \\
& Q_{l}=\frac{Q_{d} \sqrt{p_{d l}-p_{c}}}{\sqrt{p_{d}-p_{c}}},
\end{aligned}
$$

where $Q_{l}$ and $p_{d l}$ refer to diastolic forward flow and mean diastolic pressure in the presence of an aortic insufficiency.

The accuracy of these equations for use in the schema was tested by varying the stroke and stroke volume with a constant peripheral resistance and elasticity in the system rather than by attempting to separate systolic and diastolic flow. The increased stroke and stroke volume led to increased mean arterial pressures the square roots of which were proportional to the stroke volumes (Table II). By inspection it was also possible

\begin{tabular}{|c|c|c|c|c|}
\hline $\begin{array}{c}\text { Mean } \\
\text { pressure }\end{array}$ & $\begin{array}{c}\text { Capil- } \\
\text { lary } \\
\text { pressure }\end{array}$ & $\sqrt{\begin{array}{l}\text { Mean pressure } \\
\text { - capillary } \\
\text { pressure }\end{array}}$ & $\begin{array}{l}\text { Stroke } \\
\text { volume }\end{array}$ & $\begin{array}{l}\text { Calcu- } \\
\text { lated } \\
\text { stroke } \\
\text { volume* }\end{array}$ \\
\hline $\begin{array}{c}\text { mm. } \mathrm{Hg} \\
36 \\
80 \\
100\end{array}$ & $\begin{array}{c}m m . H g \\
21 \\
21 \\
21\end{array}$ & $\begin{array}{l}3.88 \\
7.69 \\
8.90\end{array}$ & $\begin{array}{l}c c . \\
1.42 \\
2.72 \\
3.31\end{array}$ & $\begin{array}{l}c c . \\
2.75 \\
3.26\end{array}$ \\
\hline
\end{tabular}
to show that flow from the capillaries was uniform during systole and diastole when the elas-

TABLE II

Effect of increasing stroke volume on mean arterial pressures with constant peripheral resistance and elasticity

* Calculated stroke volume determined by equation

$$
\frac{1.42}{X}=\frac{\sqrt{p_{1}-p_{c}}}{\sqrt{p_{2}-p_{c}}}
$$


ticity in the arteries was high and the pulse pressures therefore low (pulse pressure $=2 \mathrm{~mm}$. $\mathrm{Hg}$ with a mean blood pressure of $120 \mathrm{~mm} . \mathrm{Hg}$ ), and that there was considerable variation in systolic and diastolic flow when the arterial system was more rigid with a considerable difference between mean systolic and mean diastolic pressure (120 $\mathrm{mm} . \mathrm{Hg}$ and $80 \mathrm{~mm}$. $\mathrm{Hg}$, respectively).

The assumption that there is no change in the size of the capillaries between systole and diastole is probably not entirely correct and has been disputed in the case of lesions of the aortic valve $(3,4)$, but it is important to note that if there is any deviation it is most probably small rather than large. The quantity of diastolic flow in aortic insufficiency estimated by the use of this equation is sufficiently less than that found under normal conditions to account for the appearance of a capillary pulse in this valvular disorder.

Referring again to the analogy of the standpipe (Figure 2), the amount of fluid leaving the reservoir when there is an additional opening (a leak) in unit time, and the amount leaving it in the same time through only the original opening (the capillaries) are proportional as are their respective differences in height (pulse pressures).

This fact makes possible a third equation:

$$
\frac{Q_{d}}{X+Q_{l}}=\frac{p p_{d}}{p p_{l}}
$$

where $Q_{d}$ and $Q_{l}$ are diastolic flow without and with a leaking aortic valve (as before), $p p_{d}$ and $p p_{l}$ are pulse pressures without and with aortic insufficiency and $X$ is the amount which regurgitates into the left ventricle.

Substituting for $Q_{d}$ and $Q_{l}$ and solving for $X$ :

$$
X=\frac{V T_{d}\left(p p_{l} \sqrt{p_{d}-p_{c}}-p p_{d} \sqrt{p_{d l}-p_{c}}\right)}{p p_{d}\left(T_{s} \sqrt{p_{s}-p_{c}}+T_{d} \sqrt{p_{d}-p_{c}}\right)}
$$

This formula for the calculation of the amount of fluid which regurgitates into the left ventricle was tested on the model. Only a few of many observations in which the agreement was close are given (Table III).

It will be noted (Table III) that when all of the factors used in the calculation of results on the model (systolic and diastolic times were equal and cancelled out) were roughly proportionate fractions of animal and human pressures and vol-

TABLE III

\begin{tabular}{|c|c|c|c|c|c|c|c|c|c|}
\hline \multicolumn{4}{|c|}{ Intact valves } & \multicolumn{5}{|c|}{ Aortic insufficiency } & \multirow[b]{2}{*}{ Remarks } \\
\hline $\begin{array}{c}\text { Output } \\
\text { per } \\
\text { beat }\end{array}$ & $\begin{array}{c}\text { Pulse } \\
\text { pressure }\end{array}$ & $\begin{array}{l}\text { Mean } \\
\text { diastolic } \\
\text { pressure }\end{array}$ & $\begin{array}{l}\text { Mean } \\
\text { systolic } \\
\text { pressure }\end{array}$ & $\begin{array}{c}\text { Pulse } \\
\text { pressure }\end{array}$ & $\begin{array}{l}\text { Mean } \\
\text { diastolic } \\
\text { pressure }\end{array}$ & $\begin{array}{l}\text { Observed } \\
\text { leak "un- } \\
\text { compen- } \\
\text { sated" }\end{array}$ & $\begin{array}{c}\text { Observed } \\
\text { leak } \\
\text { "compen- } \\
\text { sated" }\end{array}$ & $\begin{array}{l}\text { Calcu- } \\
\text { lated } \\
\text { leak }\end{array}$ & \\
\hline $\begin{array}{c}c c . \\
1.90 \\
1.87 \\
1.91\end{array}$ & $\begin{array}{c}m m . H g \\
7 \\
4 \\
7\end{array}$ & $\begin{array}{c}m m . H g \\
5 \\
5 \\
5\end{array}$ & $\begin{array}{c}\text { mm. } \mathrm{Hg} \\
7 \\
7 \\
7\end{array}$ & $\begin{array}{c}m m . H g \\
14 \\
8 \\
14\end{array}$ & $\begin{array}{c}m m . H g \\
3 \\
5 \\
2\end{array}$ & $c c$ & $\begin{array}{l}c c . \\
1.1 \\
0.7 \\
1.2\end{array}$ & $\begin{array}{c}c c . \\
1.07 \\
0.85 \\
1.20\end{array}$ & $\begin{array}{l}\text { Roughly proportionate fraction of ani- } \\
\text { mal output per beat and pressure }\end{array}$ \\
\hline $\begin{array}{l}.93 \\
.93 \\
.93\end{array}$ & $\begin{array}{l}22 \\
22 \\
22\end{array}$ & $\begin{array}{l}81 \\
81 \\
81\end{array}$ & $\begin{array}{l}86 \\
86 \\
86\end{array}$ & $\begin{array}{l}44 \\
35 \\
28\end{array}$ & $\begin{array}{l}76 \\
76 \\
76\end{array}$ & & $\begin{array}{l}0.45 \\
0.30 \\
0.20\end{array}$ & $\begin{array}{l}0.47 \\
0.28 \\
0.14\end{array}$ & $\begin{array}{l}\text { Same original condition with different } \\
\text { sized leaks }\end{array}$ \\
\hline .93 & 22 & 81 & 86 & 40 & 50 & 0.33 & & 0.47 & "Uncompensated" leak \\
\hline $\begin{array}{l}2.71 \\
2.68 \\
2.68 \\
2.64 \\
2.68 \\
2.61\end{array}$ & $\begin{array}{r}4 \\
5 \\
7 \\
12 \\
18 \\
34\end{array}$ & $\begin{array}{r}96 \\
102 \\
107 \\
109 \\
110 \\
110\end{array}$ & $\begin{array}{r}98 \\
104 \\
110 \\
113 \\
116 \\
120\end{array}$ & $\begin{array}{l}12 \\
13 \\
17 \\
23 \\
31 \\
54\end{array}$ & $\begin{array}{l}90 \\
90 \\
92 \\
94 \\
94 \\
95\end{array}$ & $\begin{array}{l}0.61 \\
0.61 \\
0.60 \\
0.57 \\
0.61 \\
0.59\end{array}$ & $\begin{array}{l}1.1+ \\
1.1+ \\
1.1 \\
1.1 \\
1.1- \\
1.1-\end{array}$ & $\begin{array}{l}2.80 \\
2.20 \\
1.97 \\
1.30 \\
1.06 \\
0.86\end{array}$ & $\begin{array}{l}\text { (Extreme elasticity) } \\
\text { Varying elasticity } \\
\text { (Extreme rigidity) }\end{array}$ \\
\hline $\begin{array}{l}1.90 \\
1.91 \\
1.89\end{array}$ & $\begin{array}{l}9 \\
4 \\
4\end{array}$ & $\begin{array}{r}16 \\
30 \\
108\end{array}$ & $\begin{array}{r}25 \\
32 \\
110\end{array}$ & $\begin{array}{l}20 \\
27 \\
42\end{array}$ & $\begin{array}{l}14 \\
25 \\
90\end{array}$ & $\begin{array}{r}.80 \\
1.03 \\
1.29\end{array}$ & $\begin{array}{l}1.10 \\
1.8+ \\
4.5+\end{array}$ & $\begin{array}{l}1.08 \\
5.43 \\
9.23\end{array}$ & $\begin{array}{l}\text { Excessive elasticity and same actual } \\
\text { leak with increasing resistance }\end{array}$ \\
\hline 0.95 & 10 & 140 & 146 & 22 & 132 & & 0.50 & 0.36 & "Right ventricle" active \\
\hline
\end{tabular}

Comparison of calculated with observed leaks in the schema 
ume flows, the calculated leaks agreed fairly well with the observed leaks.

The widest discrepancy was observed when there was greater elasticity in the arterial system than exists in animals, especially when accompanied by an excessively high mean arterial pressure in proportion to stroke volume. The elasticity was regarded as excessive when, with large stroke volumes at high mean arterial pressures, the pulse pressures remained small. If the elasticity in the arterial reservoirs in these discordant experiments had been comparable to that in ani-

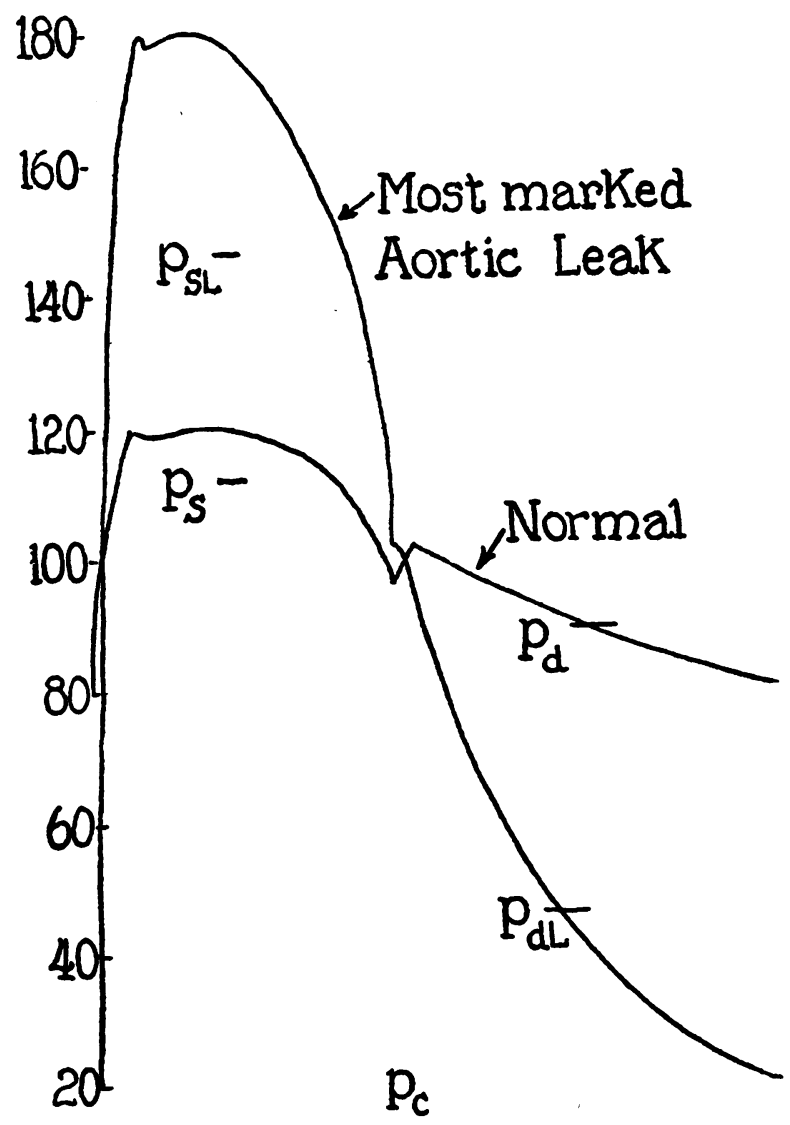

\section{$0.33 \mathrm{Sec} . \quad 0.67$}

Fig. 3. Hypothetical Human Aortic Pressure Curves Using Data from Wiggers (3) and Hamilton et al. (2) for the Shapes of the Curves, and Time Relations From AdAMS (12).

pa1, pa, par, pa and pe represent mean systolic pressure with and without aortic insufficiency, mean diastolic pressure with and without a leak and mean capillary pressure, respectively. mals, such stroke volumes would result in higher pulse pressures at high mean pressures $(8,9)$.

The use of this formula in animal or human aortic insufficiency is of doubtful value; such complicated hydrodynamic systems are better studied empirically. But at present no technic is available with which to appraise the facts in animals or human beings. There is justification, therefore, in the use of a formula the results of using which agree as closely as does this one under natural and artificial conditions.

Theoretical considerations which may lead to incorrectly high calculations include, 1-the rôle played by the elasticity and tone of the aorta, 2the tandem activity of the two ventricles, 3erroneous assumptions as to what constitutes compensation, for the formula presupposes that compensation is present and assumes the restoration of usual volume flow to the tissues.

1. The part played by elasticity in the schema has already been discussed. In animals and man no serious bar to accuracy need occur unless arterial tone modifies elasticity at low mean arterial pressures in an important way. If arterial tone leads to greater rigidity at these levels and the natural limit of elasticity is approached at high mean pressures, each of these factors would result in a greater pulse pressure per unit change in volume than in the middle range of mean pressures (9). Increased rigidity, whether from arterial tone or from high mean pressures, would tend to exaggerate the gross stroke volume change including the amount of insufficiency that would occur as suggested by Equation 4 (Table IV). Calculations of smaller and moderate size leaks would not be affected, however, and those of

TABLE IV

Calculated leaks in hypothetical human aortic insufficiency

\begin{tabular}{|c|c|c|c|c|c|c|}
\hline \multirow{2}{*}{$\begin{array}{l}\text { Diastolic } \\
\text { arterial } \\
\text { pressure }\end{array}$} & \multicolumn{6}{|c|}{ Systolic arterial pressure, $(\mathrm{mm} . \mathrm{Hg})$} \\
\hline & 130 & 140 & 150 & 160 & 170 & 180 \\
\hline $\begin{array}{c}\text { mm. } H g \\
70 \\
60 \\
50 \\
40 \\
30 \\
20\end{array}$ & $\begin{array}{l}c c . \\
15 \\
23 \\
31 \\
39 \\
47 \\
55\end{array}$ & $\begin{array}{l}c c . \\
21 \\
29 \\
37 \\
45 \\
53 \\
61\end{array}$ & $\begin{array}{l}c c . \\
28 \\
35 \\
44 \\
51 \\
60 \\
68\end{array}$ & $\begin{array}{l}c c . \\
34 \\
42 \\
50 \\
58 \\
66 \\
74\end{array}$ & $\begin{array}{l}c c . \\
40 \\
48 \\
57 \\
64 \\
73 \\
81\end{array}$ & $\begin{array}{l}c c . \\
47 \\
55 \\
63 \\
71 \\
79 \\
87\end{array}$ \\
\hline
\end{tabular}


larger leaks only slightly. The rôle played by elasticity affects the use of the formula in a way that makes the italicized figures (Table IV), where mean arterial pressures are comparable to supposed mean arterial pressures with intact valves, probably more accurate than the remaining figures. The formula supposes the presence of normal elasticity. Normal elasticity is assumed to exist when the systolic pressure is 120 $\mathrm{mm}$. $\mathrm{Hg}$, the diastolic, $80 \mathrm{~mm}$. $\mathrm{Hg}$, the valves intact, and the output normal.

2. The tandem activity of the two ventricles affects the volume output per beat but not the calculation of the leak, unless the right ventricle is dominant, a condition which is not encountered in human beings.

3. Compensation is accomplished in aortic insufficiency by maintenance of the normal cardiac output and often by the normal output per beat $(10,11)$. The output per beat is assumed to be $50 \mathrm{cc}$. at a rate of 70 per minute. The leak, according to Equation 4, varies directly with the stroke volume when the valves are intact. If $50 \mathrm{cc}$. is high, the leaks will also be proportionally high. Since the cardiac output is 3.5 liters under these circumstances, a close approximation to "normal" $(10,11)$ has been attained.

Other factors might operate to make the calculations of the insufficiency smaller than the actuality. Among these are (a) the arbitrary use of low $(20 \mathrm{~mm} . \mathrm{Hg})$ capillary pressures rather than higher arteriolar ones, and $(b)$ the fact that diastolic intraventricular pressure is higher in animals than in the schema. Negative intraventricular pressure theoretically operates in favor of an increase in inflow from the mitral orifice rather than from the aorta through a defect in the aortic valve because the difference in pressures in the left auricle and in the aorta becomes relatively less as intraventricular pressure becomes more negative. (c) A third factor is the fact that systole is longer and diastole correspondingly shorter in electrocardiograms than when measured in mechanical records $(0.38$ second for systolic time and 0.47 second for diastolic time (12) were used).

The figures for the amounts which flow back in human aortic insufficiencies (Table IV) are compatible with experience under many different conditions in the model and are reasonable from the clinical and pathological point of view. The largest calculated leak would entail a gross stroke volume output of $137 \mathrm{cc}$. (87 cc. regurgitated (Table IV) plus $50 \mathrm{cc}$. output per beat) which would seem possible when the enlargement of the left ventricular chamber known to be common in severe examples of this valvular disease is considered.

The amount of leak plus the net stroke volume makes possible the calculation of work done by the left ventricle. Hamilton has shown that the velocity factor of work done by the left ventricle is an appreciable amount and is demonstrable in animals as an elevation of intraventricular pressure above aortic pressure (13). The increased gross stroke volume in aortic insufficiency increases this velocity factor. If this factor is disregarded the following simple formula may be used :

$$
\text { Work (H.W.U.) }=(V+X) p_{s l},
$$

where H.W.U. equals an arbitrary work unit, ${ }^{1}$ $V$ equals net stroke volume, $X$ equals the amount of leak and $p_{8 l}$ equals mean systolic arterial pressure in presence of a leak (derived from Wiggers' curves). The calculations of work done by the left ventricle with various size leaks show that the work increases with increase in the size of the valvular defect (Table V).

An attempt has been made $(10,14)$ to utilize left ventricular work and heart size in proposing an index of the function of cardiac muscle. While this is a promising approach it should be noted that when data for cases of aortic insufficiency with presumed impending myocardial insufficiency are recalculated on the basis of this formula the relationship is altered so that the cases fall well within the normal range. Thus Case 24 (14) has a calculated grammeter per beat of 123 instead of 43, Case 57 (10), 81 instead of 34 and Case 201 (10), 156 instead of 52.5. These calculations represent changes in the values

\footnotetext{
1 A work unit is employed which avoids multiplication of the results by factors representing absolute work units. A new and simple work unit for clinical purposes is legitimate and desirable. The use of absolute work units creates an illusion of accuracy not justified by the facts in this and other calculations of cardiac work. The work unit, which is $1 \mathrm{cc}$. of blood times $1 \mathrm{~mm}$. $\mathrm{Hg}$ pressure, is here designated as a "heart work unit" (H.W.U.).
} 
TABLE $\mathbf{v}$

Calculated basal work per beat of the left ventrical in hypothetical human aortic insufficiency*

\begin{tabular}{|c|c|c|c|c|c|c|c|c|c|c|c|c|}
\hline \multirow{3}{*}{$\begin{array}{l}\text { Diastolic } \\
\text { arterial } \\
\text { pressure }\end{array}$} & \multicolumn{12}{|c|}{ Systolic arterial pressures, $\left(m m . H_{g}\right)$} \\
\hline & \multicolumn{2}{|c|}{130} & \multicolumn{2}{|c|}{140} & \multicolumn{2}{|c|}{150} & \multicolumn{2}{|c|}{160} & \multicolumn{2}{|c|}{170} & \multicolumn{2}{|c|}{180} \\
\hline & $\begin{array}{c}\text { Work } \\
\text { in } \\
\text { H.w.U. }\end{array}$ & $\begin{array}{c}\text { Per cent } \\
\text { of } \\
\text { normal } \\
\end{array}$ & $\begin{array}{c}\text { Work } \\
\text { in } \\
\text { H.w.U.t }\end{array}$ & $\begin{array}{c}\text { Per cent } \\
\text { of } \\
\text { normal }\end{array}$ & $\begin{array}{c}\text { Work } \\
\text { in } \\
\text { H.W.U.† }\end{array}$ & $\begin{array}{c}\text { Per cent } \\
\text { of } \\
\text { normal }\end{array}$ & $\begin{array}{c}\text { Work } \\
\text { in } \\
\text { H.W.U.† }\end{array}$ & $\begin{array}{c}\text { Per cent } \\
\text { of } \\
\text { normal }\end{array}$ & $\begin{array}{c}\text { Work } \\
\text { in } \\
\text { H.W.U.t }\end{array}$ & $\begin{array}{c}\text { Per cent } \\
\text { of } \\
\text { normal }\end{array}$ & $\begin{array}{l}\text { Work } \\
\text { in } \\
\text { H.W.U.† }\end{array}$ & $\begin{array}{c}\text { Per cent } \\
\text { of } \\
\text { normal }\end{array}$ \\
\hline$m m . \mathrm{Hg}$ & & & & & & & & & & & & \\
\hline $\begin{array}{l}70 \\
60 \\
50 \\
40 \\
30 \\
20\end{array}$ & $\begin{array}{r}7570 \\
8500 \\
9449 \\
10380 \\
11320 \\
12240\end{array}$ & $\begin{array}{l}135 \\
152 \\
169 \\
185 \\
203 \\
219\end{array}$ & $\begin{array}{r}8680 \\
9650 \\
10620 \\
11600 \\
12600 \\
13600\end{array}$ & $\begin{array}{l}155 \\
172 \\
190 \\
207 \\
225 \\
243\end{array}$ & $\begin{array}{r}9930 \\
10950 \\
11990 \\
13000 \\
14030 \\
15050\end{array}$ & $\begin{array}{l}177 \\
196 \\
214 \\
232 \\
251 \\
269\end{array}$ & $\begin{array}{l}11250 \\
12320 \\
13390 \\
14480 \\
15590 \\
16650\end{array}$ & $\begin{array}{l}201 \\
220 \\
239 \\
258 \\
278 \\
298\end{array}$ & $\begin{array}{l}12670 \\
13780 \\
14900 \\
16020 \\
17150 \\
18300\end{array}$ & $\begin{array}{l}226 \\
246 \\
266 \\
286 \\
306 \\
327\end{array}$ & $\begin{array}{l}14120 \\
15280 \\
16470 \\
17620 \\
18820 \\
20020\end{array}$ & $\begin{array}{l}252 \\
273 \\
294 \\
315 \\
337 \\
358\end{array}$ \\
\hline
\end{tabular}

* Basal work with intact valves $=50 \times 112=5600$ H.W.U.

$\dagger$ For explanation see footnote 1 , page 648 .

of the systolic mean pressures based on reconstructed curves mentioned before as well as changes in the gross stroke volume.

The heart, as opposed to the left ventricle only, must do increased work in other valvular lesions such as mitral stenosis, a fact readily shown on the schema but not calculable in living man. Increased work would alter the ratio of heart work to heart size for all valvular lesions and make necessary a revision of the conception of this ratio as an index of function. It may well be that the ratio is important in actual heart failure but reliable figures on output are difficult to obtain at present in that state. The ratio may also be important as a means of estimating cardiac work in patients with compensated valvular lesions of a type which does not permit the direct calculation of work.

Since no technic is at present available for estimating the immediate or future capacities of the left ventricle in a given case to do work, these figures cannot be used except to give a conception of the enormous increase in work continuously necessary in this valvular lesion.

\section{SUMMARY AND CONCLUSIONS}

1. Increasing amounts of fluid regurgitate into the "left ventricle" of a schema of the circulation in the presence of increasingly large "aortic insufficiencies."

2. A formula for the calculation of these amounts has been constructed using peripheral findings measurable in man, assumptions which seem valid and are compatible with known physical laws.

3. The formula gives comparable results to the leaks measured in the schema when elasticity, stroke volumes and mean pressures are proportionate fractions of their values in animals and man.

4. The formula applied to hypothetical human aortic insufficiencies of various sizes gives approximations of the amount of regurgitation which vary from $15 \mathrm{cc}$. to $87 \mathrm{cc}$. per beat with an assumed net stroke volume of $50 \mathrm{cc}$. and a rate of 70 per minute. A discussion of the accuracy of the approximations and the factors affecting it reveals no important large source of error.

5. The work of the left ventricle in these hypothetical cases is calculated from the gross stroke and mean systolic arterial pressure omitting the probably important velocity factor and still amounting to 135 to 358 per cent of basal work with intact valves.

\section{BIBLIOGRAPHY}

1. Lewis, T., and Drury, A. N., Observations relating to arterio-venous aneurism. I. Circulatory manifestations in clinical cases with particular reference to the arterial phenomena of aortic regurgitation. Heart, 1923, 10, 301.

2. Hamilton, W. F., Brotman, I., and Brewer, G., Changes in volume and velocity of blood flow in chronic experimental aortic regurgitation and the effect of certain drugs in this condition. Am. J. Physiol., 1934, 107, 414.

3. Wiggers, C. J., Studies on the pathological physiology of the heart. II. The dynamics of aortic insufficiency. Arch. Int. Med., 1915, 16, 132. 
4. Stewart, H. A., Experimental and clinical investigation of the pulse and blood pressure changes in aortic insufficiency. Arch. Int. Med., 1908, 1, 102.

5. Wiggers, C. J., Theisen, H., and Williams, H. A., Further observations on experimental aortic insufficiency. II. Cinematographic studies of changes in ventricular size and in left ventricular discharge. J. Clin. Invest., 1930, 9, 215.

6. Bay, E. B., and Jacobs, H. (To be published.)

7. Merriman, M., Treatise on Hydraulics. John Wiley and Sons, New York, 1890.

8. Bramwell, J. C., Downing, A. C., and Hill, A. V., The effect of blood pressure on the extensibility of the human artery. Heart, 1923, 10, 289.

9. Wiggers, C. J., Modern Aspects of the Circulation in Health and Disease. Lea and Febiger, Philadelphia, 1923, p. 639.

10. Starr, I., Jr., Donal, J. S., Margolies, A., Shaw, R.,
Collins, L. H., and Gamble, C. J., Studies of the heart and circulation in disease; estimations of basal cardiac output, metabolism, heart size and blood pressure in 235 subjects. J. Clin. Invest., 1934, 13, 561.

11. Grollman, A., The Cardiac Output of Man in Health and Disease. Charles C. Thomas, Springfield, 1932.

12. Adams, W., The normal duration of the electrocardiographic ventricular complex. J. Clin. Invest., 1936, 15,335 .

13. Hamilton, W. F., and Brackett, F. S., Dynamic considerations on the relation between aortic and intraventricular pressure curves. Am. J. Physiol., 1935, $112,130$.

14. Starr, I., Jr., Collins, L. H., Jr., and Wood, F. C., Studies of the basal work and output of the heart in clinical conditions. J. Clin. Invest., 1933, 12, 13. 